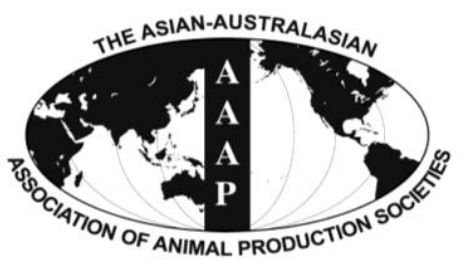

Open Access

Asian Australas. J. Anim. Sci.

Vol. 28, No. 2 : 180-187 February 2015

http://dx.doi.org/10.5713/ajas.14.0443

www.ajas.info

pISSN 1011-2367 elSSN 1976-5517

\title{
Effect of By-product Feed-based Silage Feeding on the Performance, Blood Metabolites, and Carcass Characteristics of Hanwoo Steers (a Field Study)
}

\author{
Y. I. Kim, J. M. Park, Y. H. Lee, M. Lee, D. Y. Choi, and W. S. Kwak* \\ Division of Food Biosciences, College of Health and Medical Life Sciences, \\ Konkuk University, Chung-Ju 380-701, Korea
}

\begin{abstract}
This study was conducted to determine the effects of feeding by-product feed (BF)-based silage on the performance, blood metabolite parameters, and carcass characteristics of Hanwoo steers. The BF-based silage was composed of 50\% spent mushroom substrate, $21 \%$ recycled poultry bedding, $15 \%$ cut ryegrass straw, $10.8 \%$ rice bran, $2 \%$ molasses, $0.6 \%$ bentonite, and $0.6 \%$ microbial additive (on a wet basis), and ensiled for over $5 \mathrm{~d}$. Fifteen steers were allocated to three diets during the growing and fattening periods (3.1 and 9.8 months, respectively): a control diet (concentrate mix and free access to rice straw), a 50\% BF-based silage diet (control diet $+50 \%$ of maximum BF-based silage intake), and a $100 \%$ BF-based silage diet (the same amount of concentrate mix and ad libitum BF-based silage). The BF-based silage was fed during the growing and fattening periods, and was replaced with larger particles of rice straw during the finishing period. After 19.6 months of the whole period all the steers were slaughtered. Compared with feeding rice straw, feeding BF-based silage tended $(\mathrm{p}=0.10)$ to increase the average daily gain $(27 \%)$ and feed efficiency $(18 \%)$ of the growing steers, caused by increased voluntary feed intake. Feeding BF-based silage had little effect on serum constituents, electrolytes, enzymes, or the blood cell profiles of fattening steers, except for low serum $\mathrm{Ca}$ and high blood urea concentrations $(\mathrm{p}<0.05)$. Feeding BF-based silage did not affect cold carcass weight, yield traits such as back fat thickness, longissimus muscle area, yield index or yield grade, or quality traits such as meat color, fat color, texture, maturity, marbling score, or quality grade. However, it improved good quality grade $\left(1^{+}\right.$and $\left.1^{++}\right)$appearance rates $(60 \%$ for the control group vs $100 \%$ for the BF-based silage-fed groups). In conclusion, cheap BF-based silage could be successfully used as a good quality roughage source for beef cattle. (Key Words: Spent Mushroom Substrate, Byproduct Feed, Silage, Meat Quality, Steer, Hanwoo)
\end{abstract}

\section{INTRODUCTION}

Feeding a cheap by-product feed, such as spent mushroom substrate (SMS), can reduce feed cost. Sawdustbased SMS contains too much moisture (over 60\%) and neutral detergent fiber (NDF, 78.2\%), and too low crude protein (CP, 7.2\%) and energy content (Bae et al., 2006). The storage of SMS is problematic, as it putrefies quickly due to its high moisture content (Kwak et al., 2008). Therefore, to improve the nutritive quality of sawdust-based SMS, it should be mixed with other complementary feed

* Corresponding Author: Wan-Sup Kwak. Tel: +82-43-8403521, Fax: +82-43-8518675, E-mail: wsk@kku.ac.kr

Submitted Jun. 15, 2014; Revised Aug. 28, 2014; Accepted Sept. 11, 2014 sources

Feeding good quality roughage to growing beef cattle can be an important way to produce well-marbled beef (Sainz et al., 1995). Feeding good quality Timothy hay (Matsumoto, 1999; Kim, 2006) or Klein grass hay (Kwon et al., 2009) to beef steers during the growing period improves growth and meat quality. Replacing poor quality rice straw with proteinaceous Timothy and alfalfa hay increases body weight gain and produces well-marbled beef (Kim et al., 2007a; Oh et al., 2007).

Previous studies have reported that cheap, good quality by-product feed (BF)-based roughage can be successfully manufactured by ensiling SMS, recycled poultry bedding $(\mathrm{RPB})$, rice bran, and a minimal amount of straw, with 
added molasses and highly cellulolytic microbes, which were isolated from SMS (Kim et al., 2007b; 2008; 2014). The silage exhibits favorable ensiling characteristics and has a higher degradability of dry matter (DM) and CP than do rice straw or ryegrass straw (Kim et al., 2014).

This study was conducted to determine the effects of feeding BF-based silage on the performance, blood metabolite parameters, and carcass characteristics of Hanwoo steers.

\section{MATERIALS AND METHODS}

\section{Manufacture of by-product feed-based silage}

The SMS was collected fresh from a local oyster mushroom (Pleurotus ostreatus) farm. The original mushroom substrate consisted of $47 \%$ sawdust, $18 \%$ kapok meal, $18 \%$ beet pulp, $13 \%$ corncobs, and $4 \%$ cottonseed meal. The BF-based silage was manufactured as described in Kim et al. (2014) at the experimental farm of Konkuk University located in Chung-Ju city in Chung-Buk province. The SMS (50\%) was mixed with RPB (21\%), cut ryegrass straw $(15 \%)$, rice bran $(10.8 \%)$, molasses $(2 \%)$, bentonite $(0.6 \%)$, and microbial additive $(0.6 \%)$, and ensiled in two folds of polyvinyl bags that were placed in a 1-ton capacity plastic bag for $5 \mathrm{~d}$ to $4 \mathrm{wk}$. The chemical composition of the BF-based silage ingredients is shown in Table 1. The microbial inoculants used in this experiment were isolated and identified previously in our lab (Kim et al., 2007b; 2008), and included Enterobacter ludwigii KU201-3, Bacillus cereus KU206-3, Bacillus subtilis KU3, Saccharomyces cerevisiae, and Lactobacillus plantarum. The mixture was inoculated with the strains (each added at $0.12 \%$ [v/w]). Bacillus sp. and Enterobacter sp. were cultured in plate count broth ( $5 \mathrm{~g}$ casein, $2.5 \mathrm{~g}$ yeast extract, and $1 \mathrm{~g} / \mathrm{L}$ dextrose) at $36^{\circ} \mathrm{C}$ for $24 \mathrm{~h}$, Saccharomyces sp. was cultured in yeast malt broth (0711, Difco Laboratories
Inc., Detroit, MI, USA) at $30^{\circ} \mathrm{C}$ for $48 \mathrm{~h}$, and Lactobacillus sp. was cultured in de Man, Rogosa and Sharpe (MRS) broth (0881, Difco Laboratories Inc.) at $36^{\circ} \mathrm{C}$ for $24 \mathrm{~h}$.

\section{Animals and treatments}

All animal care protocols were approved by the Konkuk University Institutional Animal Care and Use Committee. Six- to seven-month old Hanwoo steers were acclimatized to the experimental farm over 3 months. Fifteen Hanwoo steers (a mean age of 10.9 months and a mean body weight [BW] of $254.4 \pm 1.0 \mathrm{~kg}$ ) were randomly assigned to three pens ( 5 steers/pen/treatment). Each pen was $50 \mathrm{~m}^{2}$ in area $(5 \mathrm{~m} \times 10 \mathrm{~m})$. The feeding phases were composed of growing (3.1 months), fattening (9.8 months), and finishing (6.7 months) phases.

Steers were fed one of three diets: a control diet (formulated concentrate mix and free access to rice straw), a modification of the control diet which consisted of the control diet $+50 \%$ of the maximum BF-based silage intake (50\% BF-based silage), and a 100\% BF-based silage diet, which consisted of concentrate mix and ad libitum BFbased silage as a roughage source. The BF-based silage was fed during the growing and fattening periods, and was replaced with larger particles of rice straw during the finishing period. During the growing and fattening periods, the steers had free access to rice straw, but were restricted to $1.2 \mathrm{~kg} / \mathrm{d}$ (as-fed basis) during the finishing period.

The amount of formulated concentrate mix was calculated based on the BW of cattle fed the $100 \%$ BFbased silage diet. All the treated groups were fed the same amount of concentrate mix. The growing period was from 9 to 13 months of age, during which all the steers were fed a mean concentrate mix of $1.75 \%$ (as-fed basis) of BW. The fattening period was from 14 to 23 months of age, during which all the steers were fed a mean concentrate mix of $1.85 \%$ of $\mathrm{BW}$. The finishing period was from 24 to 30

Table 1. Chemical composition of by-product feed-based silage ingredients ${ }^{1}$

\begin{tabular}{|c|c|c|c|c|c|c|}
\hline Item & $\mathrm{SMS}^{2}$ & Ryegrass straw & RPB & Rice bran & Molasses & Bentonite \\
\hline & ----- & 910 & - & $\begin{array}{l}\text { I basis -- } \\
833\end{array}$ & - & $\begin{array}{l}000 \\
----1\end{array}$ \\
\hline $\begin{array}{l}\text { Dry matter } \\
\text { Crude protein }\end{array}$ & $\begin{array}{l}30.9 \\
13.4\end{array}$ & $\begin{array}{c}91.0 \\
4.2\end{array}$ & $\begin{array}{l}70.0 \\
16.5\end{array}$ & $\begin{array}{l}83.3 \\
13.9\end{array}$ & $\begin{array}{c}65.7 \\
5.8\end{array}$ & $\begin{array}{c}90.0 \\
-\end{array}$ \\
\hline Ether extract & 0.6 & 0.1 & 0.8 & 12.6 & 0.2 & - \\
\hline Neutral detergent fiber & 76.7 & 81.0 & 42.9 & 20.6 & 6.8 & - \\
\hline Acid detergent fiber & 61.2 & 56.1 & 38.5 & 7.6 & 6.0 & - \\
\hline Hemicellulose & 15.5 & 24.9 & 4.4 & 13.0 & 0.8 & - \\
\hline Non-fibrous carbohydrate & 4.5 & 9.4 & 17.2 & 46.0 & 75.0 & - \\
\hline Crude ash & 4.9 & 5.3 & 22.6 & 7.0 & 12.2 & 90.0 \\
\hline Calcium & 2.4 & 0.3 & 2.3 & 0.1 & 0.6 & 1.8 \\
\hline Phosphorus & 0.4 & 0.1 & 1.5 & 2.0 & 0.1 & 0.1 \\
\hline
\end{tabular}

SMS, spent mushroom substrates; RPB, recycled poultry bedding.

${ }^{1}$ BF-based silage was by-product feed-based silage, which was composed of $50 \%$ spent mushroom substrates, $21 \%$ recycled poultry bedding, $15 \%$ ryegrass straw, $10.8 \%$ rice bran, $2 \%$ molasses, $0.6 \%$ bentonite, and $0.6 \%$ microbial additive, and ensiled for $5 \mathrm{~d}$ to $4 \mathrm{wk}$.

${ }^{2}$ The original mushroom substrates consisted of $47 \%$ sawdust, $18 \%$ kapok meal, $18 \%$ beet pulp, $13 \%$ corncobs, and $4 \%$ cottonseed meal. 
months of age, during which the steers had free access to the concentrate mix. Concentrate mix availability was limited during the growing and fattening periods, in order to prevent excessive gain. The total experimental feeding period was 18.6 months.

Feed was supplied twice a day (07:00 and 18:00). Animals always had free access to fresh water. The BW of the steers was measured monthly throughout the feeding trial using a scale (Cas, BI-2RB, Yangju, Korea). Feed DM and $\mathrm{CP}$ intake, average daily gain (ADG), and feed efficiency were measured monthly.

\section{Blood parameters}

A health diagnosis was conducted during the fattening period, when the BF-based silage was fed to the steers. Blood samples were taken from the jugular vein and added equally into bottles with or without anti-coagulant ethylenediaminetetraacetic acid. Serum profiles were analyzed using an Automatic Biochemical Analyzer (Hitachi 7170A, Hitachi Ltd., Tokyo, Japan), using the photometer and ion selective electrode methods, and whole blood profiles were analyzed using an Automatic Blood Analyzer (Coulter STKS, Beckman Coulter Co., Miami, FL, USA), based on the impedance and VCS (volume, conductivity, and light scattering) methods.

\section{Carcass characteristics}

Back fat thickness, marbling score, and longissimus muscle area were measured at 26.2 and 29.2 months of age using ultrasound (Aloka SSD-500, Hitachi Aloka Medical, Ltd., Wallingford, CT, USA). Steers were withdrawn from the experimental diets $24 \mathrm{~h}$ before slaughter. Following a 48-h carcass chill, the yield and quality grade of each carcass was measured using Korean carcass grading standards specified in Korean Livestock Enforcement Regulation (KMAF, 2007). Quality grades were classified as $1^{++}$(very high quality), $1^{+}, 1,2$, and 3 (low quality). Back fat thickness and longissimus muscle area were measured at the 13th rib. Yield index was calculated as follows: yield index $=68.184-(0.625 \times$ back fat thickness $[\mathrm{mm}])+\left(0.130 \times\right.$ longissimus muscle area $\left.\left[\mathrm{cm}^{2}\right]\right)-$ $(0.024 \times$ cold carcass weight $[\mathrm{kg}])+3.23$. Yield grades were classified as $\mathrm{A}$ (high yield), $\mathrm{B}$, and $\mathrm{C}$ (low yield): grade $\mathrm{A}=$ higher than 67.5 , grade $\mathrm{B}=$ higher than 62.0 and lower than 67.5 , and grade $\mathrm{C}=$ lower than 62.0. The grading ranged between 1 and 27, with higher numbers indicating better quality; marbling ( 1 = devoid, 27 = abundant $)$; meat color ( 1 = bright cherry red, 7 = extremely dark red); fat color $(1$ = white, $7=$ dark yellow $)$; texture $(1=$ soft, $3=$ firm $)$; maturity $(1=$ youthful, 9 = mature $)$.

\section{Chemical and microbial analysis}

Representative samples of the test feeds that were fed to the Hanwoo steers were collected and stored at $-20^{\circ} \mathrm{C}$ for later analysis. Immediately before the analysis, all the samples were dried and ground to pass through a 1-mm filter using a sample mill (Cemotec, Tecator, Sweden). The DM fraction was quantified by drying the samples at $60^{\circ} \mathrm{C}$ for $48 \mathrm{~h}$ to reach a constant weight. The $\mathrm{CP}$, ether extract (EE), NDF, acid detergent fiber (ADF), and crude ash were determined by the AOAC method (2000). The non-fibrous carbohydrate (NFC) content was calculated as 100-(NDF\% $+\mathrm{CP} \%+\mathrm{EE} \%+$ crude ash\%). The true protein (TP) content was measured by evaluating the nitrogen fractions precipitated in a 5\% trichloroacetic acid solution. The nonprotein nitrogen (NPN)-CP fraction was calculated as $\mathrm{CP}-$ TP. The indigestible protein (ADF-CP) content was determined using the method described by Van Soest et al. (1991). Calcium and phosphorus were analyzed according to the mineral analysis method of the Standard Analysis Protocol for Feeds (KMAF, 2010). The chemical compositions of the diets are shown in Table 2. Compared with rice straw, BF-based silage had a 3.8-fold higher $\mathrm{CP}$ level, which is similar to that of good quality Timothy (Kim et al., 2007a), a $4.5 \%$ point high EE, and a $27.9 \%$ point low NDF.

Microbial analyses of the samples (sample size, $25 \mathrm{~g}$ ) were conducted according to the AOAC (2000) method, as follows: the total bacterial count was determined on plate count agar (Difco Laboratories Inc., Detroit, MI, USA) incubated at $30^{\circ} \mathrm{C}$ for $48 \mathrm{~h}$. The lactic acid bacterial count was determined on MRS agar plates (Difco Laboratories Inc., USA) incubated at $36^{\circ} \mathrm{C}$ for $24 \mathrm{~h}$. The yeast count was determined on yeast malt agar plates (Difco Laboratories Inc., USA) incubated at $36^{\circ} \mathrm{C}$ for $48 \mathrm{~h}$. The lactic acid bacterial count of BF-based silage was $7.4 \log _{10} \mathrm{cfu} / \mathrm{g}$ and the yeast count was $4.5 \log _{10} \mathrm{cfu} / \mathrm{g}$.

\section{Statistical analysis}

Data were subjected to one-way analysis of variance using the general linear model procedure (Statistix7, 2000). A comparison of the means of the control, $50 \%$ BF-based silage, and the $100 \%$ BF-based silage diets was made using Tukey's multiple range test (Statistix7, 2000). Significant differences were detected if $\mathrm{p}<0.05$.

\section{RESULTS AND DISCUSSION}

\section{Body weight gain and feed intake}

During the growing period, the complete replacement of rice straw with BF-based silage tended to increase the ADG by $0.19 \mathrm{~kg}(\mathrm{p}=0.10)$ (Table 3). Feeding BF-based silage that contained a 3.8-fold higher level of $\mathrm{CP}$ than rice straw tended to improve $\mathrm{BW}$ gain during the growing period. However, BW gain during the fattening and finishing periods was similar between the treatments. There was no 
Table 2. Chemical composition of feeds fed to Hanwoo steers ${ }^{1}$

\begin{tabular}{|c|c|c|c|c|c|}
\hline \multirow{2}{*}{ Item } & \multirow{2}{*}{ Rice straw } & \multirow{2}{*}{ BF-based silage $^{2}$} & \multicolumn{3}{|c|}{ Concentrate mix } \\
\hline & & & Growing & Fattening & Finishing \\
\hline & & & $\%$----- & 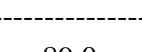 & 070 \\
\hline Dry matter & 81.3 & 63.8 & 89.2 & 89.0 & 87.2 \\
\hline Crude protein $(\mathrm{CP})$ & 3.4 & 12.6 & 16.1 & 14.7 & 13.2 \\
\hline True protein/CP & 77.5 & 53.2 & 64.7 & 61.0 & 72.5 \\
\hline Non-protein N/CP & 22.5 & 46.8 & 35.3 & 39.0 & 27.5 \\
\hline Acid detergent fiber- $\mathrm{CP} / \mathrm{CP}$ & 80.9 & 23.2 & 6.6 & 6.5 & 8.4 \\
\hline Ether extract & 0.9 & 4.0 & 2.8 & 2.7 & 2.0 \\
\hline Crude ash & 12.3 & 11.1 & 7.4 & 7.1 & 5.8 \\
\hline Neutral detergent fiber & 74.5 & 52.7 & 29.8 & 28.4 & 21.7 \\
\hline Acid detergent fiber & 44.9 & 35.3 & 15.7 & 10.9 & 8.6 \\
\hline Non-fibrous carbohydrate & 8.9 & 19.6 & 43.8 & 47.1 & 57.3 \\
\hline Calcium & 0.3 & 1.4 & 0.9 & 0.9 & 0.9 \\
\hline Phosphorus & 0.1 & 0.5 & 0.6 & 0.5 & 0.5 \\
\hline
\end{tabular}

${ }^{1}$ On a dry matter basis.

${ }^{2}$ BF-based silage was by-product feed-based silage, which was composed of $50 \%$ spent mushroom substrates, $21 \%$ recycled poultry bedding, $15 \%$ ryegrass straw, $10.8 \%$ rice bran, $2 \%$ molasses, $0.6 \%$ bentonite, and $0.6 \%$ microbial additive on a wet basis, and ensiled for $5 \mathrm{~d}$ to 2 wk.

total BW gain difference between the treatments, due to compensatory growth by the control group during the fattening and finishing periods. Sainz et al. (1995) reported that limited BW gain because of restricted feeding during the growing period was compensated for during the finishing period. Also, the short finishing period ( $85 \mathrm{~d}$ ) after restricted feeding of growing steers reduced ADG in growing and finishing phase (Murphy and Loerch, 1994).
Accordingly, BF-based silage was a good source of roughage, particularly during the growing period.

There were no pen replications in this experiment, therefore feed intake was not statistically analyzed and the data are not presented. The BF-based silage was fed only during the growing and fattening periods. At 14 to 15 months old, the maximum BF-based silage DM intake was $5.4 \mathrm{~kg}$, whereas the maximum rice straw DM intake was 3.3

Table 3. Effect of feeding by-product feed-based silage on the growth $(\mathrm{kg})$ of Hanwoo steers

\begin{tabular}{|c|c|c|c|c|c|}
\hline \multirow{2}{*}{ Item } & \multirow{2}{*}{ Control } & \multicolumn{2}{|c|}{ Feeding BF-based silage $^{1}$} & \multirow{2}{*}{$\mathrm{SE}$} & \multirow{2}{*}{$\mathrm{p}$ value } \\
\hline & & $1 / 2$ of ad libitum & Ad libitum & & \\
\hline \multicolumn{6}{|l|}{ Growing period (for $3.1 \mathrm{mo}$.) } \\
\hline Initial BW (10.8 mo. old) & 251.8 & 251.4 & 259.9 & 18.6 & 0.8773 \\
\hline Final BW (13.9 mo. old) & 319.7 & 328.6 & 345.3 & 20.3 & 0.4635 \\
\hline Gain & 67.9 & 77.2 & 85.4 & 12.9 & 0.1028 \\
\hline Average daily gain & 0.71 & 0.81 & 0.90 & 0.10 & 0.1028 \\
\hline \multicolumn{6}{|l|}{ Fattening period (for $9.8 \mathrm{mo}$.) } \\
\hline Initial BW (13.9 mo. old) & 319.7 & 328.6 & 345.3 & 20.3 & 0.4635 \\
\hline Final BW (23.7 mo. old) & 560.5 & 569.6 & 575.2 & 21.7 & 0.7950 \\
\hline Gain & 240.8 & 241.0 & 229.9 & 13.1 & 0.6395 \\
\hline Average daily gain & 0.81 & 0.81 & 0.77 & 0.04 & 0.6054 \\
\hline \multicolumn{6}{|l|}{ Finishing period (for $6.7 \mathrm{mo}$.) } \\
\hline Initial BW (23.7 mo. old) & 560.5 & 569.6 & 575.2 & 21.7 & 0.7950 \\
\hline Final BW (30.4 mo. old) & 682.0 & 677.3 & 691.6 & 24.9 & 0.8622 \\
\hline Gain & 121.5 & 107.7 & 116.5 & 16.1 & 0.6954 \\
\hline Average daily gain & 0.59 & 0.53 & 0.57 & 0.08 & 0.6937 \\
\hline \multicolumn{6}{|l|}{ Whole period (19.6 mo.) } \\
\hline Initial BW (10.8 mo. old) & 251.8 & 251.4 & 259.9 & 18.6 & 0.8773 \\
\hline Final BW (30.4 mo. old) & 682.0 & 677.3 & 691.6 & 24.9 & 0.8622 \\
\hline Gain & 430.2 & 425.9 & 431.8 & 26.7 & 0.9108 \\
\hline Average daily gain & 0.72 & 0.71 & 0.72 & 0.05 & 0.9065 \\
\hline
\end{tabular}

SE, standard error; BW, body weight.

${ }^{1}$ BF-based silage was by-product feed-based silage, which was composed of $50 \%$ spent mushroom substrates, $21 \%$ recycled poultry bedding, $15 \%$ ryegrass straw, $10.8 \%$ rice bran, $2 \%$ molasses, $0.6 \%$ bentonite, and $0.6 \%$ microbial additive on a wet basis, and ensiled for $5 \mathrm{~d}$ to 4 wk.

${ }^{\mathrm{a}, \mathrm{b}, \mathrm{c}}$ Means with different superscripts within the same row are significantly different $(\mathrm{p}<0.05)$. 
$\mathrm{kg}$. This might be attributed to the better palatability and smaller particle size $(<19 \mathrm{~mm}$ size $=83 \%)$ of BF-based silage, which rapidly leaves the rumen, increasing its passage rate to the lower digestive tract (Martz and Belyea, 1986). Feeding ad libitum BF-based silage during the growing and fattening periods did not decrease the concentrate mix intake during the finishing period.

The feed efficiency of steers fed ad libitum BF-based silage increased by $17.9 \%$ during the growing period compared to that of steers fed rice straw (data not presented). The increased intake of DM and CP and the increased ADG and feed efficiency of growing steers fed BF-based silage indicate that the diet was particularly effective during the growing period.

\section{Blood parameters}

Constituents and electrolytes: Compared with feeding rice straw, feeding BF-based silage up to ad libitum at 22.7 months of age did not affect blood constituents, such as: serum triglyceride, cholesterol, high density lipoprotein, low density lipoprotein, glucose, or total protein (Table 4). These results indicate that fat, energy, and protein metabolism were not affected by feeding BF-based silage.

The serum electrolytes $\mathrm{P}, \mathrm{K}, \mathrm{Na}$, and $\mathrm{Cl}$ were not affected by feeding BF-based silage, except for low serum $\mathrm{Ca}$ in the steers fed 50\% BF-based silage $(\mathrm{p}<0.05)$. The serum $\mathrm{Ca}$ concentration is maintained within very narrow limits by calcitonin and parathyroid hormone (McDowell, 2003). However, the reason for the low serum $\mathrm{Ca}$ in $50 \%$ BF-based silage-fed steers cannot be explained by this study. The repeatability of this phenomenon requires further monitoring. Most blood constituent and electrolyte levels were within the normal range for healthy cattle (Wallach, 1974; Church and Pond, 1982).
Other blood parameters: Compared with feeding rice straw, feeding BF-based silage did not affect serum levels of albumin, globulin, alkaline phosphatase, alanine aminotransferase, aspartate aminotransferase, creatinine phosphokinase, lactate dehydrogenase, creatinine, or the albumin/globulin ratio, the urea-N/creatinine ratio, the white blood cell count, the red blood cell count, or the platelet count of fattening Hanwoo steers (Table 5). Levels of these blood parameters were within the normal range (Wallach, 1974; Church and Pond, 1982).

The blood enzyme results indicate that there was little effect of feeding BF-based silage on liver function. Compared with feeding 50\% BF-based silage, feeding ad libitum BF-based silage increased the serum albumin/globulin ratio and favorably decreased serum alanine aminotransferase concentrations $(p<0.05)$. Serum alanine aminotransferase is related to liver cell function. In the present study, it appears that feeding BF-based silage did not deleteriously affect liver function.

Blood urea-N (BUN) and serum creatinine levels are used as indices of renal function. Compared with the control group, BUN increased in the group fed ad libitum BF-based silage $(\mathrm{p}<0.05)$, probably because of a higher dietary CP and NPN intake. Chumpawadee et al. (2006) and Javaid et al. (2008) reported that changing levels of BUN are similar to those of ruminal $\mathrm{NH}_{3}-\mathrm{N}$. In addition, BUN increases as nitrogen retention in the muscle decreases (Enright et al., 1990). In general, excessive BUN levels indicate damaged kidney function, sometimes followed by kidney urolith occurrence. Normal levels of BUN vary between 7 and $30 \mathrm{mg} / \mathrm{dL}$ (Wallach, 1974; Church and Pond, 1982). In this study, the BUN levels in the group fed ad libitum BF-based silage were within the normal range. A blood test was conducted during the finishing period (at

Table 4. Blood constituents and electrolytes of fattening Hanwoo steers fed different diets

\begin{tabular}{|c|c|c|c|c|c|}
\hline \multirow{2}{*}{ Item } & \multirow{2}{*}{ Control } & \multicolumn{2}{|c|}{ Feeding BF-based silage $^{2}$} & \multirow{2}{*}{$\mathrm{SE}$} & \multirow{2}{*}{$\mathrm{p}$ value } \\
\hline & & $1 / 2$ of ad libitum & Ad libitum & & \\
\hline Triglyceride (mg/dL) & 34.1 & 31.9 & 53.0 & 9.0 & 0.070 \\
\hline Cholesterol (mg/dL) & 84.1 & 86.4 & 84.5 & 7.8 & 0.951 \\
\hline High density lipoprotein (mg/dL) & 33.9 & 30.5 & 31.1 & 2.4 & 0.341 \\
\hline Low density lipoprotein (mg/dL) & 29.9 & 28.2 & 28.5 & 2.1 & 0.689 \\
\hline Glucose (mg/dL) & 137.6 & 136.9 & 132.0 & 8.0 & 0.755 \\
\hline Total protein $(\mathrm{g} / \mathrm{dL})$ & 7.1 & 6.8 & 7.2 & 0.2 & 0.263 \\
\hline \multicolumn{6}{|l|}{ Electrolytes } \\
\hline $\mathrm{Ca}^{+}(\mathrm{mg} / \mathrm{dL})$ & $9.3^{\mathrm{a}}$ & $8.7^{\mathrm{b}}$ & $8.8^{\mathrm{ab}}$ & 0.2 & 0.015 \\
\hline Inorganic $\mathrm{P}^{-}(\mathrm{mg} / \mathrm{dL})$ & 8.0 & 7.7 & 8.5 & 0.4 & 0.166 \\
\hline $\mathrm{K}^{+}(\mathrm{mmol} / \mathrm{L})$ & 6.0 & 6.3 & 6.0 & 0.3 & 0.531 \\
\hline $\mathrm{Na}^{+}(\mathrm{mmol} / \mathrm{L})$ & 141.6 & 140.4 & 140.0 & 1.0 & 0.270 \\
\hline $\mathrm{Cl}^{-}(\mathrm{mmol} / \mathrm{L})$ & 103.0 & 102.0 & 102.0 & 0.9 & 0.485 \\
\hline
\end{tabular}

SE, standard error.

${ }^{1}$ Blood sampled at 22.7 months of age.

${ }^{2}$ BF-based silage was by-product feed-based silage, which was composed of $50 \%$ spent mushroom substrates, $21 \%$ recycled poultry bedding, $15 \%$ ryegrass straw, $10.8 \%$ rice bran, $2 \%$ molasses, $0.6 \%$ bentonite, and $0.6 \%$ microbial additive on a wet basis, and ensiled for $5 \mathrm{~d}$ to $4 \mathrm{wk}$.

${ }^{\mathrm{a}, \mathrm{b}}$ Means with different superscripts within the same row are significantly different $(\mathrm{p}<0.05)$. 
Table 5. Other blood parameters of fattening Hanwoo steers fed different diets

\begin{tabular}{|c|c|c|c|c|c|}
\hline \multirow{2}{*}{ Item } & \multirow{2}{*}{ Control } & \multicolumn{2}{|c|}{ Feeding BF-based silage $^{1}$} & \multirow{2}{*}{ SE } & \multirow{2}{*}{$\mathrm{p}$ value } \\
\hline & & $1 / 2$ of ad libitum & Ad libitum & & \\
\hline \multicolumn{6}{|l|}{$\overline{\text { Fattening steers }^{2}}$} \\
\hline Albumin (g/dL) & 5.3 & 5.0 & 5.6 & 0.2 & 0.072 \\
\hline Globulin (g/dL) & 1.8 & 1.8 & 1.6 & 0.1 & 0.060 \\
\hline Albumin/globulin & 3.0 & 2.7 & 3.5 & 0.3 & 0.069 \\
\hline Alkaline phosphatase (IU/L) & 73.9 & 49.7 & 58.3 & 11.3 & 0.138 \\
\hline Alanine aminotransferase (IU/L) & $31.7^{\mathrm{ab}}$ & $37.0^{\mathrm{a}}$ & $31.0^{\mathrm{b}}$ & 2.2 & 0.039 \\
\hline Aspartate aminotransferase (IU/L) & 66.7 & 66.1 & 55.3 & 8.0 & 0.310 \\
\hline Creatinine phosphokinase (IU/L) & 261.1 & 264.9 & 296.8 & 30.6 & 0.462 \\
\hline Lactate dehydrogenase (IU/L) & 411.3 & 437.1 & 312.2 & 112.3 & 0.521 \\
\hline Urea-N (mg/dL) & $16.1^{\mathrm{b}}$ & $16.7^{\mathrm{ab}}$ & $19.0^{\mathrm{a}}$ & 0.9 & 0.023 \\
\hline Creatinine (mg/dL) & 0.9 & 1.0 & 0.9 & 0.1 & 0.809 \\
\hline Urea-N/Creatinine & 17.8 & 18.0 & 21.2 & 1.9 & 0.171 \\
\hline White blood cell counts $\left(10^{3} / \mu \mathrm{L}\right)$ & 7.1 & 5.7 & 5.9 & 3.8 & 0.418 \\
\hline Red blood cell counts $\left(10^{6} / \mu \mathrm{L}\right)$ & 8.8 & 8.4 & 8.4 & 0.6 & 0.759 \\
\hline Platelet counts $\left(10^{3} / \mu \mathrm{L}\right)$ & 323.8 & 431.2 & 578.8 & 126.9 & 0.173 \\
\hline \multicolumn{6}{|l|}{ Finishing steers ${ }^{3}$} \\
\hline Urea-N (mg/dL) & 12.1 & 10.1 & 12.1 & 1.2 & 0.227 \\
\hline Creatinine (mg/dL) & 1.5 & 1.5 & 1.4 & 0.1 & 0.804 \\
\hline Urea-N/Creatinine & 8.3 & 6.9 & 8.4 & 1.1 & 0.474 \\
\hline
\end{tabular}

SE, standard error.

${ }^{1}$ BF-based silage was by-product feed-based silage, which was composed of $50 \%$ spent mushroom substrates, $21 \%$ recycled poultry bedding, $15 \%$ ryegrass straw, $10.8 \%$ rice bran, $2 \%$ molasses, $0.6 \%$ bentonite, and $0.6 \%$ microbial additive on a wet basis, and ensiled for $5 \mathrm{~d}$ to $4 \mathrm{wk}$.

${ }^{2}$ Blood sampled at 22.7 months of age. ${ }^{3}$ Blood sampled at 28.4 months of age.

${ }^{\mathrm{ab}}$ Means with different superscripts within the same row are significantly different $(\mathrm{p}<0.05)$.

28.4 months of age) when BF-based silage was not fed, and showed that blood parameters related to kidney function did not differ between treatments. In addition, none of the steers exhibited abnormal health problems during the experimental period.

\section{Meat quantity and quality grade evaluation}

Meat evaluation by ultrasound scanning: Steers fed $50 \%$ BF-based silage had the lowest back fat thickness at 26.2 months of age $(\mathrm{p}<0.05)$, but there was no difference at 29.2 months of age (Table 6). Feeding BF-based silage did not affect the longissimus muscle area. Marbling scores were not affected by feeding BF-based silage, in spite of a trend for higher scores at 29.2 months of age in the BFbased silage-fed groups $(p=0.11)$. These results indicate that feeding BF-based silage does not deleteriously affect back fat thickness, longissimus muscle area, or marbling score. Van Koevering et al. (1995) found that marbling scores in the longissimus muscle area during the finishing phase follow a quadratic pattern, before reaching a plateau.

Carcass characteristics: Feeding BF-based silage did not affect cold carcass weight; yield traits such as back fat thickness, longissimus muscle area, yield index, or yield grade; or quality traits such as meat color, fat color, texture,

Table 6. Yield and quality traits of finishing Hanwoo steers measured by ultrasound scanning

\begin{tabular}{|c|c|c|c|c|c|c|}
\hline \multirow{2}{*}{ Item } & & \multirow{2}{*}{ Control } & \multicolumn{2}{|c|}{ Feeding BF-based silage $^{1}$} & \multirow{2}{*}{ SE } & \multirow{2}{*}{$\mathrm{p}$ value } \\
\hline & & & $1 / 2$ of ad libitum & Ad libitum & & \\
\hline \multirow[t]{2}{*}{ Back fat thickness (mm) } & 26.2 mo. old & $9.6^{\mathrm{a}}$ & $6.2^{\mathrm{b}}$ & $9.4^{\mathrm{ab}}$ & 1.3 & 0.032 \\
\hline & 29.2 mo. old & 11.3 & 9.8 & 11.5 & 1.3 & 0.448 \\
\hline \multirow[t]{2}{*}{$\operatorname{LMA}\left(\mathrm{cm}^{2}\right)$} & 26.2 mo. old & 80.7 & 81.8 & 83.7 & 2.6 & 0.520 \\
\hline & 29.2 mo. old & 88.4 & 85.6 & 88.0 & 4.8 & 0.838 \\
\hline \multirow[t]{2}{*}{ Marbling score $^{2}$} & 26.2 mo. old & 11.0 & 11.8 & 12.8 & 3.2 & 0.855 \\
\hline & 29.2 mo. old & 13.0 & 18.8 & 18.6 & 2.6 & 0.112 \\
\hline
\end{tabular}

SE, standard error; LMA, longissimus muscle area.

${ }^{1}$ BF-based silage was by-product feed-based silage, which was composed of $50 \%$ spent mushroom substrates, $21 \%$ recycled poultry bedding, $15 \%$ ryegrass straw, $10.8 \%$ rice bran, $2 \%$ molasses, $0.6 \%$ bentonite, and $0.6 \%$ microbial additive on a wet basis, and ensiled for $5 \mathrm{~d}$ to 4 wk.

${ }^{2}$ Ranges are 1 to 27 ( 1 = devoid, 27 = abundant).

a,b, Means with different superscripts within the same row are significantly different $(\mathrm{p}<0.05)$. 
maturity, marbling score, or quality grade (Table 7).

Marbling scores of the $50 \%$ BF-based silage and the $100 \%$ BF-based silage groups at slaughter were 3.2 and 4.6 points higher, respectively, than those of the control group. The difference in marbling score between treatments tended to decrease as the total feeding period extended until slaughter. A quality grade appearance rate of above $1^{+}$for the $50 \%$ BF-based silage-fed group (100\%) and the $100 \%$ BF-based silage-fed group $(100 \%)$ was more frequent than that of the control group (60\%). The $100 \%$ BF-based silagefed group had twice as many $1^{++}$grade appearance rates as the 50\% BF-based silage-fed group. These results suggest that feeding BF-based silage to Hanwoo steers may have a positive effect on the quality of beef production. In similar studies, supplementing diets with Eucommia ulmoides leaves (Kim et al., 2005) or wheat bran and green tea extract (Park et al., 2011) to Hanwoo steers increased the appearance rate of high quality grade.

In addition, the favorable results such as increased intake, ADG and feed efficiency in the growing steers fed BF-based silage seem to have resulted in more frequent appearance rates of good quality grade. Regarding this, Vasconcelos et al. (2009) reported that more intake of dietary energy increased growing phase accretion of intramuscular fat. In other aspects, fermentative end- products including organic acids might affect meat quality grade, so its mechanism needs to be further elucidated. The net farm income was $20 \%$ higher for the steers fed ad libitum BF-based silage than for those fed rice straw.

In general, compared with feeding rice straw, feeding BF-based silage tended to increase feed intake, growth, and feed efficiency of the growing steers, had little effect on serum constituents, electrolytes, enzymes, blood cell profiles of the fattening steers, and carcass yield traits or quality traits of the finishing steers, and improved to good quality grade appearance rates at slaughter.

\section{CONCLUSION}

The present results indicate that feeding BF-based silage to growing and early fattening steers could be recommendable to reduce feed cost, and improve meat quality grade and income without negative effects on animal health and carcass characteristics. Cheap BF-based silage could be successfully used as a good quality roughage source for beef cattle. The BF-based silage can be used in combination with conventional roughage to improve forage quality in Asian countries facing a roughage scarcity. A practical large-scaled research needs to be conducted to confirm the results of this study.

Table 7. Effect of feeding by-product feed-based silage on the cold carcass characteristics of Hanwoo steers slaughtered at 30.4 months of age

\begin{tabular}{|c|c|c|c|c|c|}
\hline \multirow{2}{*}{ Item } & \multirow{2}{*}{ Control } & \multicolumn{2}{|c|}{ Feeding BF-based silage $^{1}$} & \multirow{2}{*}{ SE } & \multirow{2}{*}{$\mathrm{p}$ value } \\
\hline & & $1 / 2$ of ad libitum & Ad libitum & & \\
\hline Cold carcass wt. (kg) & 432.2 & 403.6 & 445.3 & 18.6 & 0.135 \\
\hline \multicolumn{6}{|l|}{ Yield traits } \\
\hline Back fat thickness (mm) & 13.2 & 11.0 & 15.0 & 1.5 & 0.087 \\
\hline $\operatorname{LMA}\left(\mathrm{cm}^{2}\right)$ & 90.2 & 88.6 & 90.5 & 4.4 & 0.906 \\
\hline Yield index & 64.5 & 66.4 & 63.1 & 1.2 & 0.076 \\
\hline Yield grade $^{2}$ & 2.0 & 1.8 & 2.3 & 0.2 & 0.246 \\
\hline \multicolumn{6}{|l|}{ Quality traits } \\
\hline Meat color ${ }^{3}$ & 4.8 & 5.0 & 5.0 & 0.2 & 0.446 \\
\hline Fat color ${ }^{4}$ & 3.0 & 3.0 & 3.0 & 0 & 1.000 \\
\hline Texture $^{5}$ & 1.0 & 1.0 & 1.0 & 0 & 1.000 \\
\hline Maturity $^{6}$ & 2.0 & 2.0 & 2.0 & 0 & 1.000 \\
\hline Marbling score $^{7}$ & 18.4 & 21.6 & 23.0 & 2.4 & 0.214 \\
\hline Quality grade $^{8}$ & 0.42 & 0.06 & 0.03 & 0.19 & 0.119 \\
\hline \multicolumn{6}{|l|}{ Grade appearance rate } \\
\hline $1^{++}$, head $(\%)$ & $2(40)$ & $2(40)$ & $4(80)$ & - & - \\
\hline $1^{+}$, head $(\%)$ & $1(20)$ & $3(60)$ & $1(20)$ & - & - \\
\hline 1, head $(\%)$ & $2(40)$ & - & - & - & - \\
\hline
\end{tabular}

SE, standard error; LMA, longissimus muscle area.

${ }^{1}$ BF-based silage was by-product feed-based silage, which was composed of $50 \%$ spent mushroom substrates, $21 \%$ recycled poultry bedding, $15 \%$ ryegrass straw, $10.8 \%$ rice bran, $2 \%$ molasses, $0.6 \%$ bentonite, and $0.6 \%$ microbial additive on a wet basis, and ensiled for $5 \mathrm{~d}$ to 4 wk.

${ }^{2}$ Converted to a numeric: grade $\mathrm{A}=1, \mathrm{~B}=2$, and $\mathrm{C}=3 .{ }^{3}$ Meat color ranges are 1 to 7 ( $1=$ brightly cheery red, $7=$ extremely dark red).

${ }^{4}$ Fat color ranges are 1 to $7\left(1=\right.$ white, $7=$ dark yellow). ${ }^{5}$ Texture ranges are 1 to $3(1=$ soft, $3=$ firm $)$.

${ }^{6}$ Maturity ranges are 1 to 9 ( 1 = youthful, $9=$ mature $) .{ }^{7}$ Ranges are 1 to 27 ( $1=$ devoid, 27 = abundant $)$.

${ }^{8}$ Converted to a numeric: grade $1^{++}=0.01,1^{+}=0.1,1=1$, and $2=2$.

${ }^{a, b, c}$ Means with different superscripts within the same row are significantly different $(\mathrm{p}<0.05)$. 


\section{ACKNOWLEDGMENTS}

This study was supported by Konkuk University.

\section{REFERENCES}

AOAC. 2000. Official Methods of Analysis, 17th Ed. Association of Official Analytical Chemists, Washington, DC, USA.

Bae, J. S., Y. I. Kim, S. H. Jung, Y. G. Oh, and W. S. Kwak. 2006. Evaluation on feed-nutritional value of spent mushroom (Pleurotus ostreatus, Pleurotus eryngii, Flammulina velutupes) substrates as a roughage source for ruminants. Korean J. Anim. Sci. Technol. 48:237-246.

Chumpawadee, S., K. Sommart, T. Vongpralub, and V. Pattarajinda. 2006. Effects of synchronizing the rate of dietary energy and nitrogen release on ruminal fermentation, microbial protein synthesis, blood urea nitrogen and nutrient digestibility in beef cattle. Asian Australas. J. Anim. Sci. 19:181-188.

Church, D. C. and W. G. Pond. 1982. Feedstuffs for animals. In: Basic Animal Nutrition and Feeding. John Wiley and Sons. NY, USA.

Enright, W. J., J. F. Quirke, P. D. Gluckman, B. H. Breier, L. G. Kennedy, L. C. Hart, J. F. Roche, A. Coert, and P. Allen. 1990. Effects of long-term administration of pituitary-derived bovine growth hormone and estradiol on growth in steers. J. Anim. Sci. 68:2345-2356.

Javaid, A., M. M. Sarwar, and M. A. Shahzad. 2008. Ruminal characteristics, blood $\mathrm{pH}$, blood urea nitrogen and nitrogen balance in Nili-ravi Buffalo (Bubalus bubalis) bulls fed diets containing various levels of ruminally degradable protein. Asian Australas. J. Anim. Sci. 21:51-58.

Kim, B. K. 2006. Effects of feeding high quality roughage (timothy hay) during growing period on growth performance and carcass characteristics of Hanwoo steers. Korean J. Food Sci. Anim. Resour. 26:212-217.

Kim, J. H., Y. M. Kim, M. D. Lee, J. H. Shin, and Y. D. Ko. 2005. Effects of feeding Eucommia ulmoides leaves substituted for rice straw on growth performance, carcass characteristics and fatty acid composition of muscle tissues of Hanwoo steers. Korean J. Anim. Sci. Technol. 47:963-974.

Kim, S. I., G. G. Jung, J. Y. Kim, S. W. Lee, K. H. Baek, and C. B. Choi. 2007a. Effect of feeding high quality hay on performance and physico-chemical characteristics of carcass of Hanwoo steers. Korean J. Anim. Sci. Technol. 49:783-800.

Kim, Y. I., S. H. Jeong, J. S. Seok, S. Y. Yang, J. W. Huh, and W. S. Kwak. 2008. Isolation and identification of hydrolytic enzymeproducing bacteria from spent mushroom substrate. Korean J. Anim. Sci. Technol. 50:713-720.

Kim, Y. I., S. H. Jung, J. S. Seok, S. Y. Yang, J. W. Huh, and W. S. Kwak. 2007b. Isolation and identification of high cellulolytic bacteria from spent mushroom substrate and determination of optimal medium conditions for the growth. Korean J. Microbiol. Biotechnol. 35:255-260.

Kim, Y. I., Y. K. Oh, K. K. Park, and W. S. Kwak. 2014. Ensiling characteristics and the in situ nutrient degradability of a byproduct feed-based silage. Asian Australas. J. Anim. Sci. 27:201-208

Korean Ministry of Agriculture and Forest. 2007. Carcass grading standards. Livestock Regulation Practice, Appendix no. 4, KMAF, Gwacheon, Korea.

Korean Ministry of Agriculture and Forest. 2010. Notification No. 2010-29: Standard analysis method for feeds. KMAF, Gwacheon, Korea.

Kwak, W. S., S. H. Jung, and Y. I. Kim. 2008. Broiler litter supplementation improves storage and feed-nutritional value of sawdust-based spent mushroom substrate. Bioresour. Technol. 99:2947-2955.

Kwon, E. G., B. K. Park, H. C. Kim, Y. M. Cho, T. I. Kim, S. S. Chang, Y. K. Oh, N. K. Kim, J. H. Kim, Y. J. Kim, E. J. Kim, S. K. Im, and N. J. Choi. 2009. Effects of fattening period on growth performance, carcass characteristics and lipogenic gene expression in Hanwoo steers. Asian Australas. J. Anim. Sci. 22:1654-1660.

Martz, F. A. and R. L. Belyea. 1986. Role of particle size and forage quality in digestion and passage by cattle and sheep. J. Dairy Sci. 69:1996-2008.

Matsumoto, D. 1999. Fattening management program of black haired Hwawoo. In: Beef Cattle - Production and Veterinary Medicine System. Agricultural, Forestry and Fishery Culture Association, Japan. pp. 75-83.

McDowell, L. R. 2003. Minerals in Animal and Human Nutrition, 1st edition. Elsevier, Amsterdam, The Netherlands.

Murphy, T. A. and S. C. Loerch. 1994. Effects of restricted feeding of growing steers on performance, carcass characteristics, and composition. J. Anim. Sci. 72:2497-2507.

Oh, Y. G., I. S. Nam, C. W. Choi, K. H. Baek, J. H. Kim, D. H. Kim, Y. J. Seol, and K. H. Kim. 2007. Effects of different levels of $\mathrm{CP}$ intake on protein utilization and $\mathrm{N}$ excretion in varying growth stages of Hanwoo steers. Korean J. Anim. Sci. Technol. 49:369-378.

Park, B. K., N. J. Choi, S. M. Lee, H. C. Kim, B. S. Jeon, M. J. Kim, Y. K. Oh, S. K. Im, S. K. Hong, J. S. Chang, I. H. Hwang, Y. J. Kim, and E. G. Kwon. 2011. Effects of dietary multinutritional targeted supplementation according to different growth stages on performance and carcass characteristics of Hanwoo steers. Asian Australas. J. Anim. Sci. 24:222-229.

Sainz, R. D., F. De la Torre, and J. W. Oltjen. 1995. Compensatory growth and carcass quality in growth-restricted and refed beef steers. J. Anim. Sci. 73:2971-2979.

Statistix7. 2000. User's Manual. Analytical Software, Tallagassee, FL, USA.

Van Koevering, M. T., D. R. Gill, F. N. Owens, H. G. Dolezal, and C. A. Strasia. 1995. Effect of time on feed on performance of feedlot steers, carcass characteristics, and tenderness and composition of longissimus muscles. J. Anim. Sci. 73:21-28.

Vasconcelos, J. T., J. E. Sawyer, L. O. Tedeschi, F. T. McCollum, and L. W. Greene. 2009. Effects of different growing diets on performance, carcass characteristics, insulin sensitivity, and accretion of intramuscular and subcutaneous adipose tissue of feedlot cattle. J. Anim. Sci. 87:1540-1547.

Van Soest, P. J., J. B. Robertson, and B. A. Lewis. 1991. Methods of dietary fiber, neutral detergent fiber, nonstarch polysaccharides in relation to animal nutrition. J. Dairy Sci. 74:3583-3597.

Wallach, J. 1974. Interpretation of diagnostic tests, 2nd Ed. Little Brown and Company, Boston, MA, USA. 